\section{JEWELERY ART OF UKRAINE AT THE TURN OF THE XX-XXI CT.: GENESIS OF PROGRESS}

\author{
Sergii Luts, \\ https://orcid.org/0000-0001-7248-230x \\ PhD in Arts, \\ Senior Lecturer \\ of the Department of Fine \\ and Decorative Arts \\ and Restoration \\ of Works of Art, \\ Kamianets-Podilskyi \\ National Ivan Ohiienko University, \\ Kamianets-Podilskyi, Ukraine \\ luts_s@ukr.net
}

\section{Abstract}

The aim of the research is to analyze the genesis of the main factors of evolutionary transformations in the jewelry of Ukraine at the end of the XX - the beginning of the XXI ct. Research methodology. A number of scientific methods have been applied: comparativehistorical, analytical-descriptive, figurativestylistic, as well as methods of analogies and assumptions. Scientific novelty. In this study an attempt to show a generalized picture of the progress of Ukrainian jewelry on the turn of the $X X-X X I$ ct. has been made. Conclusions. It has been proved that consolidation of domestic experimental aspects in the technological field, active introduction of progressive design ideas and work experience accumulated over many years by the previous generation of masters specializing in jewelry art into the creative process has led Ukrainian jewelers to a qualitatively new stage of development. The optimal balance of traditional methods

\section{ЮВЕЛІРНЕ МИСТЕЦТВО УКРАЇНИ НА ЗЛАМІ XX-XXI СТ.: ГЕНЕЗИС ПОСТУПУ}

\section{Сергій Луць,}

https://orcid.org/0000-0001-7248-230x

кандидат мистецтвознавства,

старший викладач

кафедри образотворчого

і декоративно-прикладного

мистецтва та реставрації

творів мистецтва,

Кам'янець-Подільський національний

університет імені Івана Огієнка,

Кам'янець-Подільський, Україна

luts_s@ukr.net

\section{Анотація}

Мета дослідження - аналіз генезису основних чинників еволюційних трансформацій у ювелірному мистецтві України кін. $X X$ - поч. XXI Ст. Методологія дослідження. Застосовано ряд наукових методів: порівняльно-історичний, аналітико-описовий, образно-стилістичний, а також методи аналогій та припущень. Наукова новизна. У даному дослідженні зроблено спробу показати узагальнену картину поступу ювелірного мистецтва України на зламі XX-XXI ст. Висновки. Встановлено, що узагальнення власних експериментальних аспектів в технологічній площині, активне впровадження в творчий процес прогресивних дизайнерських ідей та напрацьованого за численні роки досвіду попереднього покоління майстрів, що спеціалізувалися на ювелірному мистецтві, вивело українських ювелірів на новий якісний етап розвитку. Оптимальне співвідношення традиційних методів та новаторських 
and innovative experimental factors of the technological and creative process in general has formed the general concept of the development of the recent Ukrainian jewelery, and promotes the birth of new creative forms of the realization of the potential of Ukrainian jewelery artists at the end of the $X X$ - the beginning of the $X X I$ ct. All these aspects help modern Ukrainian jewelery artists to adjust effectively to new principles of work and transformation on the European jewelry art market,where the philosophy of the concept of design, methods of synthesis of artistic and figurative forming as well as structural and technological forming are the main factors of the progress of the recent jewelry art in Ukraine in general.

\section{Keywords: Ключові слова:}

Ukrainian jewelery, formation, traditions, experiment, stylistics, design, shaping, art market. творення, арт-ринок. експериментальних чинників технологічного та творчого процесу загалом сформувало загальну концепцію розвитку новітнього українського ювелірства та сприяє народженню нових творчих форм реалізації потенціалу українських художників-ювелірів кін. XX - поч. XXI ст. Всі ці аспекти виводять сучасних українських митців ювелірства на шлях ефективної адаптації до нових принципів роботи та трансформації у простір європейського ювелірного арт-ринку, де філософія концепції дизайну, методів синтезу художньо-образного і конструктивнотехнологічного формотворення $€$ головними чинниками поступу новітнього ювелірного мистецтва України загалом. ції, експеримент, стилістика, дизайн, формо-

Вступ 1 Ювелірне мистецтво України другої половини XX ст. майже не виділялося із загальної концепції розвитку ювелірства радянської країни того періоду, що було зумовлено ідеологічними принципами поступу означеної галузі декоративно-прикладного мистецтва та дизайну. Аналізуючи здобутки ювелірства радянського періоду, спостерігаємо, що ідеологічний характер та сутність тогочасного устрою загалом не могли сприяти повноцінному розвитку українського ювелірного мистецтва як такого. Внаслідок домінуючої спрямованості на загальну індустріалізацію та масовотиражне виробництво, де художньо-образне мислення та концепція дизайну в цілому залишалися на задніх планах, а технологічні аспекти також не вирізнялися прогресивними методами, українське ювелірство, що в основному було представлено державними підприємствами Києва, Львова, Одеси та Харкова, цілком закономірно протягом багатьох десятиліть перебувало загалом на невисокому рівні. В країні, де ювелірна галузь була під суворим контролем, залишаючись у професійній ізоляції та практично не маючи можливості отримувати будь-яку інформацію щодо художніх та культуро-творчих процесів, новітніх технологій, які систематично впроваджувалися та відбувалися за кордоном, українські художники-ювеліри все ж намагалися ефективно працювати, опираючись здебільшого на художньо-естетичні та філософські основи власного професійного виховання. ційних трансформацій у ювелірному мистецтві України кін. $X X-$ поч. XXI ст. 
Деміург: ідеї, технології, перспективи дизайну 2019 Том 2 № 1 Demiurge: ideas, technologies, perspectives of design 2019 Vol. 2 No 1

\section{Методологія та аналіз джерельної бази}

У дослідженні використана комплексна методика, що складається з низки наукових методів, а саме: порівняльноісторичного, аналітико-описового, образно-стилістичного, а також методів аналогій та припущень.

Аналіз історіографічного матеріалу, який окреслює становлення та розвиток новітнього українського ювелірства, доводить, що наукових досліджень, які дають змогу простежити формування загальних критеріїв і вектору розвитку зазначеної галузі на зламі XX-XXI ст. та вказують на творчі здобутки художників-ювелірів у хронологічній послідовності, поки що вкрай мало. Проте, серед дослідників сучасного українського художнього металу, зокрема в галузі ювелірства, варто відзначити ряд відомих вітчизняних науковців, що активно аналізують художні процеси в царині сучасного ювелірства: Р. Шмагала (2012), 3. Чегусову (2002), Р. Шафран (2008), М. Кравченко (2014), Л. Пасічник (2015). Зазначимо, що окремі публікації у монографіях, періодиці, альбомах, каталогах, матеріалах міжнародних та всеукраїнських спеціалізованих виставок, а також інтернет-джерела слугують інформативними складовими сегментами, що загалом окреслюють окремі етапи розвитку українського ювелірства кін. XX - поч. XXI ст.

\section{Результати дослідження}

Відзначимо, що становлення авторського ювелірного мистецтва України відбувалося, починаючи з 1960-х рр., незважаючи на відсутність професійних навчальних закладів, заборону працювати з коштовними металами, брак матеріалу та необхідних інструментів. Художники-ювеліри зазначеного періоду все частіше звертаються до «самобутніх пластів культури свого народу», тим самим формуючи тверду основу для поступу сучасного українського авторського ювелірства (Пасічник, 2015, с. 91-92). Українські художники, так само як інші майстриювеліри радянського простору, за короткий проміжок часу пройшли шлях переосмислення та поступу від засвоєння традицій давньоруського мистецтва через бароко, ампір, модерн і до сучасної пластичної мови, де головним протистоянням було примітивне серійне виробництво та оригінальні твори індивідуального виконання. Здебільшого вироби авторського ювелірства 60-70 рр. XX ст. вирізнялися чіткою конструкцією, продуманими формами, використанням традиційних прийомів та мотивів, де все ж були присутні пошуки взаємодії варіювання стилізацій старих орнаментів, нових матеріалів та виражальних засобів.

Подібно до основних тенденцій «авторського мистецтва» Європи 60-х рр. XX ст., зокрема, ювелірного мистецтва, в Україні з середини 1970-х рр. відбувається утвердження українського ювелірства, де в основі $€$ «авторське начало», зумовлене індивідуальним підходом до виготовлення ювелірних предметів. «В кінці XX століття прикраси стають вираженням творчих задумів з альтернативних матеріалів (акрил, пластик, 
папір, re-cycling)», - зазначає М. Кравченко (2014) (с. 66-67). Як і європейське, українське ювелірство зазначеного періоду розвивалося в експериментальному руслі, що вирізнялося змішуванням стилів, пошуків нових методів дизайну та формотворення в цілому, ефективних виражальних засобів, поєднання нетипових для ювелірства матеріалів тощо.

Характерними особливостями дизайну авторського ювелірства 1980-х рр. стали масивні форми ювелірних прикрас, де в композицію виробів вводилося каміння здебільшого із застосуванням експериментального і фантазійного гранування, що вирізнялося різноманітними кольоровими поєднаннями. В основі композиційних схем тиражного виробництва даного періоду превалювали плавні та округлі контури, стилізовані природні мотиви, геометричний дизайн, симетрія, застосування модульної системи архітектоніки твору. На відміну від більшості західноєвропейських ювелірних домів («Булгарі», «Марина Б», «Ван Кліф і Арпельс», «Картьє», «Шоме», «Бушерон», «Граф» та ін.), де в пріоритетах були системні пошуки різних форм дизайну, що давали змогу виділитися на світовому ювелірному ринку, українські ювелірні виробництва радянського (зазначеного) періоду дотримувалися усталених методів побудови композиції із легкими варіаціями елементів сучасного дизайну (Bennett, \& Mascetti, 2003). Проте в авторському українському ювелірстві все ж відбувалися різноманітні творчі трансформації, які поступово формували фундамент для подальшого становлення та розвитку новітнього українського ювелірного мистецтва. Переоцінка попереднього художньо-технічного досвіду в 1980-1990-ті рр. виводить українське ювелірство на позиції, де домінантною є відмова від усталених стереотипів та пошуків нової образно-пластичної мови. Використання різноманітних матеріалів у оригінальній комбінаториці асоціюється з принципами роботи майстрів-ювелірів початку XX ст. Рене Лаліка, Вільгельма фон Кранаха, Оскара Массіна, Чарльза Роберта Ешбі, Люсьєна Гайара, Жоржа Фуке та інших, у яких певною мірою стираються грані між ужитковою та візуальними функціями ювелірного предмету. Доволі часто в композиціях українських художників-ювелірів, як і у дизайні відомих ювелірних компаній (таких як фірма Джоела Артура Розенталя - JAR, США, Нью-Йорк), зустрічаються вироби, що виділяються поєднанням обробленого каміння у вигляді кабошонів, оправлених у посріблену мідь, титан, алюміній тощо. Як і в ювелірстві епохи модерну, в творах українських художників-ювелірів зустрічаються флористичні та зооморфні мотиви, що транслюються у вигляді зображень тваринок, змій, метеликів, квітів, зірочок, бантів, завитків, а також абстрактних геометричних елементів: сфер, кіл, спіралей тощо. Як і європейський ювелірний дизайн 1970-1980-х рр., українське авторське ювелірство 90-х рр. XX cт. наділено ознаками поєднання індивідуального романтизму і експериментаторства, а також слугує джерелом натхнення 
й основою для розвитку нових методів ведення творчо-виробничого процесу в зазначеній царині (Bennett, \& Mascetti, 2003).

Треба відзначити, що важливим фактором у розвитку українського ювелірства нової доби було відкриття в 19601970-х рр. відділів художнього металу в навчальних художніх закладах декоративно-прикладного спрямування у Львові, Вижниці, Косові, Ужгороді, де викладачі та студенти були своєрідною рушійною силою на етапі становлення та поступу українського ювелірства кін. XX - поч. XXI ст. (Шафран, 2008; Рукотворний світ, 2011).

Одним з потужних та ініціативних колективів викладачів та студентів відділів художнього металу серед згаданих навчальних закладів, що завжди творчо експериментували в галузі ювелірства поза рамками запланованого навчального процесу, у 1980-х та 1990-х рр. були представники Вижницького училища прикладного мистецтва ім. В. Шкрібляка (нині Вижницький коледж прикладного мистецтва ім. В. Шкрібляка). Серед них - викладачі Е. Жуковський, Л. Беренфельд, В. Воронюк, О. Жуковський, І. Поп'юк, П. Прокопчик, а також велика когорта талановитих студентів-ентузіастів: С. Москаленко, С. Лемський, А. Дідковський, А. Волошенюк, І. Семенчук, Р. Окіпняк, О. Флорескул, Ю. Кирилюк, Р. Захотій, Ю. Блажко, С. Луць, С. Юрков, В. Дицьо, Д. Мамчур, М. Гуцул, І. Задорожний, О. Буйвідт, О. Куконін та інші. Саме завдяки активній творчій експериментально-дослідницькій позиції щодо композиційних та технологічних прийомів формотворення відбувалося становлення зазначених осіб саме як художників-ювелірів. Зазначимо, що в майбутньому це дало поштовх до інтенсивного впровадження творчих завдань з ювелірства в навчальний процес зазначеного закладу та утворення окремої спеціалізації ювелірства, яка працює і по нині, опираючись на навчально-методичне забезпечення, розроблене саме для цього фаху декоративноприкладного мистецтва. Враховуючи фактор активного ентузіазму зазначених особистостей, а також тверду позицію творчо розвиватися саме в цій галузі, привело до трансформування фахових пріоритетів за межі навчального закладу. Так, когорта студентів О. Флорескул, О. Тімохов, Д. Мамчур, М. Гуцул та багато інших, продовжила навчання у Південноукраїнському педагогічному університеті ім. Ушинського (м. Одеса). За ініціативи О. Флорескула був утворений відділ та сформована майстерня, де розширилося коло зацікавлених осіб вивчати та надалі продовжувати експериментально-творчі пошуки в царині ювелірства. Такі персоналії як О. Буйвідт та О. Куконін продовжили навчання у Львівській національній академії мистецтв та з часом (на поч. 2000-х рр.) свої творчі здобутки презентували на міжнародних фестивалях «Гефайстон» (Чехія), а також інших престижних спеціалізованих форумах художнього металу, де були відзначені нагородами та дипломами. Варто згадати, що І. Поп'юк продовжив викладацьку роботу в Київському держав- 
ному інституті декоративно-прикладного мистецтва і дизайну ім. М. Бойчука (нині Київська державна академія декоративноприкладного мистецтва і дизайну ім. М. Бойчука), де разом з випускником ЛНАМ А. Кулигіним широко розгорнули роботу кафедри художнього металу, зокрема в галузі ювелірства. Варто виокремити Р. Окіпняка, який, володіючи потужним творчим і технологічно-технічним арсеналом, а також - великим досвідом праці в Україні та закордоном, у 2004-2009 рр. працював на посаді викладача Академії ювелірного мистецтва (м. Одеса), де відзначився як висококваліфікований фахівець, а в 2014 р. був нагороджений орденом «Малий знак М. Перхина». Значне число талановитих випускників ВКПМ ім. В. Шкрібляка неодноразово були переможцями різних спеціалізованих культурномистецьких заходів. Так Д. Мамчур (м. Хмельницький) з декоративною композицією «Коловорот» (рис. 4.1) в 2013 р. стала переможцем Міжнародного конкурсу «Класичного ювелірного мистецтва XXI століття», що проводився КюД «Лобортас», де здобула I місце в номінації «Скульптура (мілка пластика)», а В. Дицьо (м. Одеса) здобув II місце в номінації «Ювелірна робота (предмет)». Також у 2015 р. Д. Мамчур здобула гран-прі в номінації «Краща срібна прикраса» на Міжнародній виставці «Ювелір - Експо - Україна».

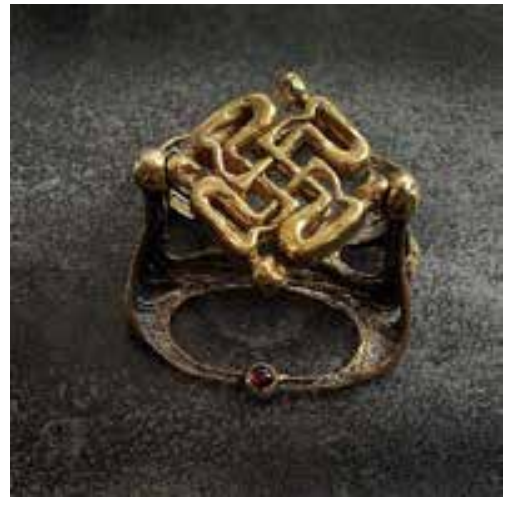

Рис. 4.1. Д. Мамчур. Декоративна композиція «Коловорот». Хмельницький. 2013. Бронза, гранат, оксидування. Лиття, авторська техніка, ручне моделювання та монтування. Власність автора. Фото Д. Мамчур.

Fig. 4. 1. D. Mamchur. Decorative composition "Kolovorot». Khmelnytskyi. 2013. Bronze, pomegranate, oxidation. Casting, author's technique, manual modeling and mounting. The property of the author. Photo by D. Mamchur.

Початок першого десятиліття XXI ст. позначився сплеском розвитку ювелірства у Косівському інституті прикладного та декоративного мистецтва ЛНАМ, де яскраво вирізняється творчо-педагогічна праця О. Гаркуса (старшого викладача, завідувача кафедри художнього металу). Він згуртував студентів, які з ентузіазмом продукують сучасне українське ювелірство, композиційні схеми яких вирізняються етномотивами, що яскраво характеризують даний регіон країни. Серед них А. Корчмин (м. Прилуки), Я. Савчук (с. Розтоки, Івано-Франківська обл.), А. Свирид (с. Вербовець, Івано-Франківська обл.), В. Богаченко (м. Косів, Івано-Франківська обл.), А. Савчук та О. Савчук (м. Кам'янець-Подільський) та ін. (Рукотворний світ, 2011, с. 108-111). 
Слід також виокремити представників Київського державного інституту декоративно-прикладного мистецтва і дизайну ім. В. Бойчука, котрі внесли значний внесок у становлення та розвиток сучасного ювелірства, що відзначилися активною творчою позицією та є значимими учасниками у розбудові нових прогресивних якісних змін у царині ювелірного мистецтва України поч. XXI ст. Серед них - І. Юрков, О. Барбалат, Л. Довгошей та багато інших.

Загалом відзначимо, що переважна більшість випускників спеціалізацій художнього металу після закінчення навчальних закладів акумулювали та спрямували свій творчий потенціал саме у галузь ювелірства, що, безперечно, принесло велику користь для утворення загальної концепції розвитку новітнього українського ювелірного мистецтва. Треба відмітити, що кожний навчальний заклад сформував власну стилістику та концепцію формотворення ювелірних виробів, що відтворює певні характерні традиції у цій галузі відповідних географічноетнічних регіонів країни.

Дослідження передумов становлення та розвитку ювелірного мистецтва в Україні періоду незалежності на зламі XX-XXI ст. засвідчує: нині вітчизняне ювелірство впевнено вийшло на нову якісну стадію свого поступу, зумовлену, головним чином, пріоритетами творчої свободи та національними цінностями, що яскраво відображається у творах сучасних українських художників-ювелірів.

Беручи до уваги нинішній стан розвитку сучасного українського ювелірства, стає очевидним, що відродження даного виду декоративно-прикладного мистецтва та дизайну в зазначеній галузі складає потужну ланку у формуванні загальної концепції культуро-творчого процесу країни. Поступ українського ювелірства кін. XX - поч. XXI ст. тісно пов'язаний з соціокультурними тенденціями історико-геополітичного простору та яскравими виражальними засобами, що покладені на національну основу. Останні десятиліття XX ст. позначилися формуванням художньообразної системи, яка базується на розмаїтті інтерпретацій міфів, легенд, сакральних знаків і символів, історії та релігії, що є вагомою складовою в образній структурі українського та світового ювелірного мистецтва. Зазначені ознаки у синтезі з новаторськими креативними вирішеннями дизайнерських завдань та технологічних експериментів, а також різноманітних методів формотворення, в основі яких закладені традиційні класичні ювелірні техніки, дали феноменальні результати, що характеризуються відповідними художніми процесами, які відображені у творчості представників сучасного українського ювелірства. Провідні місця у цьому просторі належать як представникам авторського ювелірства, так і творчим колективам, що функціонують у форматах державних та приватних ювелірних підприємств, широкий ряд яких нині є зразком системного 
поетапного творчого зростання в контексті формування загальноукраїнського ювелірного арт-ринку (Шмагало, 2012).

Відзначимо, що останнє десятиліття минулого століття в українському ювелірстві позначилося бурхливим розвитком і нестримним бажанням художників та зацікавлених осіб долучитися до творчих процесів у цій галузі. Вакуум, що утворився в радянські часи, де приватне ювелірство було заборонене, почав стрімко заповнюватися новими іменами авторського ювелірства та брендами ювелірних фірм. Отримавши довгоочікувану свободу творчості, художники-ювеліри доти ще з не розкритим потужнім творчим потенціалом, що базувався на традиціях та досвіді майстрів попередніх поколінь, розпочали різносторонній процес технологічних експериментів, креативних підходів та методів пошуку новаторських вирішень композиційних та формотворчих завдань. Завдяки відкритому інформаційному простору та можливості перебувати за межами країни на спеціалізованих виставках, фестивалях, симпозіумах, українські художники-ювеліри ще з більшим стремлінням та фаховими амбіціями розкрилися в царині ювелірного мистецтва. Це підтверджується високими творчими результатами, що засвідчують дипломи та нагороди багатьох спеціалізованих заходів. Поступово сформувалася ціла плеяда художників та майстрів новітнього українського ювелірства, які з фанатичним захопленням стрімко стверджувалися на вітчизняному та світовому арт-ринку. Серед корифеїв, які ще в 70-80-х рр. XX ст. заклали фундамент новітнього українського ювелірства, варто відзначити когорту майстрів, більшість з яких і нині знаходяться в активному творчому процесі. Тут яскраво вирізняються В. Хоменко, В. Балибердін, С. Сєров, В. Заварзін, $€$ Є. Друзенко, О. Міхальянц, Ю. Федоров, С. Капітонов, Ю. Жданов, С. Вольський, Г. Хоменко, О. Жарков, М. Руснак та багато інших художників-ювелірів, які представляють різні регіони країни. Відзначимо, що початок 1990-х рр. вибухнув якісним числом творчих особистостей, що своїм новаторським розмаїттям художньо-образних та технологічних процесів ефективно доповнили палітру визнаних майстрів українського ювелірства. Серед них - Ш. Пержан, К. Кравчук, О. Мірошніков, В. Шоломій, О. Івасюта, С. Микита, Р. Велігурський, А. Шерстюк, О. Дрокін, А. Волський та інші (рис. 4.2). Яскравими представниками творчої генерації початку нового століття, які нині $є$ впевненим та логічним продовженням розбудови загальної концепції сучасного українського ювелірного мистецтва, є багато художників, які творчо експериментують у різних напрямах і стилях, та відзначилися вже в першому десятилітті XXI ст., використовуючи при цьому потужній арсенал традиційних ювелірних технік, цікавих композиційних прийомів сучасного дизайну і новаторських формотворчих процесів. До цього ряду відносяться: О. Барбалат, О. Гаркус, Р. Гарматюк, В. Крохмалюк, О. Буйвідт, А. Кулигін, В. Лєсогор, А. Болюх, Петрів, Д. Мамчур, В. Дицьо, 


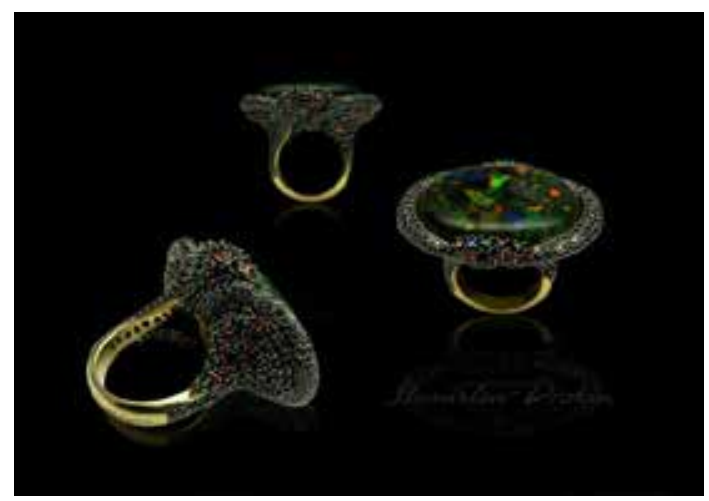

Рис. 4.2. С. Дрокін. Каблучка. Харків. 2000-ні. Срібло. Авторські техніки, ручне моделювання та монтування. Фото С. Дрокіна

Fig. 4.2. S. Drokin. Rabbit. Kharkiv. 2000. Silver. Author's technique, manual modeling and mounting. Photo by S. Drokina.

О. Окіпняк, М. Франко, А. Савчук, В. Бабій, брати Кочути та багато інших (Чегусова, 2002; Пасічник, 2015; Рукотворний світ, 2011).

Аналізуючи загальну картину поступу сучасного українського ювелірного мистецтва, варто зупинитися на характерних ознаках творчості окремих яскравих представників цього процесу, що безпосередньо вплинули на формування системи загальних засад поступу вітчизняного ювелірства. Кожний із зазначених художників-ювелірів вирізняється власними художньо-стилістичними концепціями, принципами та методами формотворення, використанням тих чи інших матеріалів.

Позицією активного експериментаторства та впровадженням нових технологічних прийомів формотворення позначена творчість відомого київського художника Віталія Хоменка ідейного організатора ряду виставок і симпозіумів, присвячених ювелірному та емальєрному мистецтву в Україні. Так, з ініціативи зазначеного митця у 1978 р., у колі відомих вже на той час художників-ювелірів О. Жаркова, Ю. Жданова, О. Міхальянца, Ю. Федорова, Л. Косигіна, а також колег із Прибалтики, Грузії, Вірменії, Росії, була презентована виставка-симпозіум у Будинку художника України. Акція привернула увагу як фахівців, так і поціновувачів ювелірного мистецтва, та, як зазначає мистецтвознавець Л. Пасічник, стала «цінним досвідом для майстрів і певним поштовхом до обміну мистецькими ідеями та розвитку художньої думки ювелірів України» (Пасічник, 2012, с. 27). Треба зазначити, що В. Хоменко і надалі залишається мотивованим об'єднавчими та організаторськими діями, що ведуть до презентації виставкових проектів «10 грамів мелодії» (2004) та «Квадра міні-метал» (2014), де за підтримки однодумців (куратор проекту Л. Пасічник) втілює в життя задумане та у черговий раз генерує творчий поступ молодого покоління художників новітнього українського авторського ювелірства. Власна творчість В. Хоменка ґрунтується на зверненні до «історичних пластів культури нашого народу, його пращурів, опанування надбаннями світової культури» (Чегусова, 2002, с. 380). Художня образність митця наділена особливим відчуттям поєднання різноманітних за характером та формою еле- 
ментів, що вводяться у композиційні схеми та вирізняються чіткою завершеністю динамічних чи статичних конструкцій, використанням традиційних для ювелірства матеріалів (золота, срібла, різноманітного коштовного та напівкоштовного каміння), що звучать акцентами в загальній архітектоніці ювелірних творів. Використовуючи традиційні технологічні прийоми у поєднанні з новаторськими методами роботи в ювелірстві для реалізації ідеї творчого задуму художник знаходиться «у постійному пошуку форми, співзвучної часу», про що свідчить еволюція його творчості починаючи з 70-х рр. кін. XX ст. і понині (Чегусова, 2002, с. 380-381). Майстер віртуозно володіє комплексом традиційних технологічних операцій та потужним арсеналом класичних ювелірних технік, що завжди вирізняються новаторськими методами роботи. Він використовує широкий спектр поліхромії коштовних та інших матеріалів (золото, срібло, гарячі емалі, діаманти, рубіни, гранати, олександрити, благородний опал, демантоїди, хризоліти, рожевий кварц, аметист, мушля, перли, перламутр тощо). Серед відомих творів майстра - мисливський набір «Хмелю, мій хмелю» (1997-1999), гарнітур «Літо» (1997), що насичені рослинними елементами та тяжіють до барокової стилістики; шпилька «Береги» (1986), брошка із серії «Агресивна перевага» (1987), брошки «Паланга», «Комета Галея», «Ніда» із серії «Прибалтійські етюди» (1984), де звучать ноти авангардного мистецтва, що обумовлені геометричними чи абсолютно абстрактними асиметричними динамічними конструкціями; кольє «Зірка Волині» (2001), брошка «Спіраль часу» (2007-2008), «Аборигени планети Земля» (2012), перстень «Вечірній захід» (2014), гарнітур «Зимові вишні» (2012), підвісок «Туманний ранок» (2014) тощо (Музей історичних коштовностей України; Чегусова, 2002; Шмагало, 2015; Пасічник, 2014). Твори останнього періоду розкривають багатогранний діапазон творчих напрацювань майстра, що позначені змішуванням різних стилів та тяжіють до постмодерного звучання. Можна стверджувати, що творчість В. Хоменка $є$ виразним відображенням всіх етапів становлення та загального поступу новітнього українського ювелірного мистецтва на межі XX-XXI ст.

Творчість відомого львівського художника-ювеліра Станіслава Вольського у сучасному українському ювелірному мистецтві позиціонується як зразок високого класу художньо-технічної майстерності, що демонструє органічне єднання художньо-образної романтики рослинного світу та визрілого арсеналу ювелірних технік, яким уміло користується митець. Ювелірство майстра апелює до синтезу пластичної та колірної експресії, що відображено яскравою індивідуальністю засобів виразності технологічних прийомів, зокрема майже забутої у XX ст. давньої техніки гарячої емалі, тим самим сприяючи оновленню та збагаченню художньо-образної мови у створенні цілої низки творів високого фахового рівня. Переосмисливши 
сутність декоративності зазначеної техніки, художник акцентує увагу на естетиці ювелірних творів не тільки як засобів декору, але й концептуального візуального мистецтва, яким окрім його прямого функціонального призначення можна просто насолоджуватися. Специфіка художньо-емоційної мови тієї чи іншої техніки та якостей матеріалу, що використовує митець (гарячі емалі, різьблення по каменю, широкий діапазон та багатогранність прийомів металопластики) в цілому сформували творчий напрям і визначили індивідуальну виразність майстра, що знайшла місце в загальному спектрі жанру так званого «art jewelery», який набув популярності у XX ст. Як зазначає доктор мистецтвознавства Р. Шмагало, «різні партії каміння, металів чи емалі естетично об'єднані нотками насиченого, кокетливограйливого колориту єдиної формальної ідеї. Серії квіткових композицій стають полем для унікальних експериментів з емаллю на об'ємній формі» (Шмагало, 2015, с. 145). Серед відомих ювелірних творів (рис. 4.3), що відтворюють характер творчості С. Вольського, вирізняються: кольє «Хвиля» (1980, мельхіор, перламутр, перли, гаряча емаль), комплект: брошка і сережки (1996, золото, гаряча емаль, смарагд, діаманти), браслет (2001, золото, бірюза), намисто «Лідія» (2001, золото, бірюза), кулон (2002, золото, цитрин, діаманти), перстень «Троянда» (2003, золото, гаряча емаль, діаманти), перстень «Весна» $(2003$, золото, гаряча емаль, сапфіри, діаманти), браслет «Літо» (2007, золото, гаряча емаль, діаманти), перстень «Сюрприз» (2008, золото, берил, діаманти), скульптурна композиція «Кактус IV» (2001, срібло, золото, агат, діаманти, гаряча емаль), кольє «Нефертіті» (2008, топаз, сапфіри, діаманти, золото, емаль), брошка «Лілія» (2008, золото, діаманти, емаль) (Вольський (Б. р.); Шмагало, 2008).

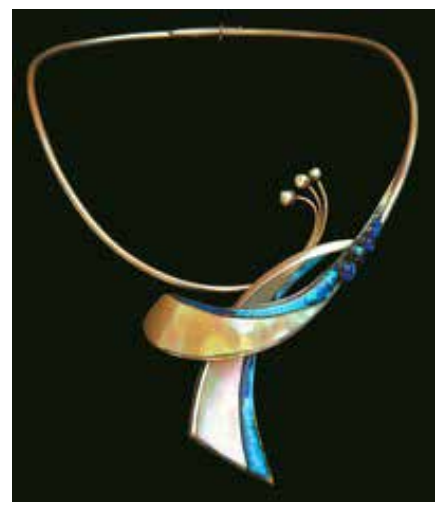

Рис. 4.3. С. Вольський. Кольє «Хвиля». Львів. 1980 Мельхіор, перламутр, перли, гаряча емаль. Дифування, гнуття, ручне моделювання та монтування. Приватна колекція. Фото О. Введенського.

Fig. 4.3. S. Volskyi. Necklace «Wave». Lviv. 1980. Melchior, mother-of-pearl, pearls, hot enamel. Diffusion, bending, manual modeling and mounting. Private collection. Photo by O. Vvedensky.

Початок 90-х рр. XX ст. ознаменувався інтенсивними пошуками нових виражальних засобів, принципів та методів дизайну і формотворення, розкриттям образного змісту через асоціативний ряд інтерпретацій характерних символів та знаків, що ідентифікують українське ювелірство у світовому культурно- 
мистецькому просторі. В цей час відбувається становлення великої когорти майстрів та привертає до себе увагу, зокрема творчість буковинських художників-ювелірів з м. Чернівців - Костянтина Кравчука та Штефана Пержана, що сформували власну пластичну мову завдяки синтезу відпрацьованих прийомів стилізації та новаторських поєднань технологічних процесів із використанням різного роду матеріалів. Ювелірні твори К. Кравчука (періоду 90-х XX ст. рр.) характеризуються комбінаціями контрасту площин та ліній, що звучать протистоянням поєднань різних фактур і тональних градацій того чи іншого матеріалу, де графічність абстрагованого декору заповнюється елементами з використанням технік випилювання та зерні (Шмагало, 2015, с. 141). Творчості К. Кравчука притаманне поєднання неоавангардної стилістики з національними традиціями, що виливається у власну манеру виконання ювелірних творів митця, про що свідчать гарнітури: «Всесвіт» (1996, срібло, каміння), «Мелодія» (1997), «Стожари» (1999), «Ніч» (1999), кольє «Міраж» (1997), брошки «Марево» (1998), «Політ» (1997), «Мамина казка» (поч. XXI ст., срібло, каміння), кольє «Диско, кольє «Місячна доріжка» (Гран-прі, премія «За найкращий дизайн» Міжнародного конкурсу «Сучасна ювелірна мода» фірми «Signiti», Швейцарія), кольє та перстень «БуйТур» (срібло, агати), кольє «Сонцеворот» (срібло, гранати, сапфіри, шкіра), браслет «Посланець Всесвіту» (срібло, вулканічна маса), кольє «Благовіст» (рис. 4.4), комплект: браслет та перстень «Павутинка» (срібло, раух-топаз) тощо (Рукотворний світ, 2011, с. 57; Шмагало, 2015, с. 164-165). Художник активно використовує срібло та інші метали, широку палітру напівкоштовного каміння та різноманітних матеріалів, де присутні: сапфір, гранат, агат, онікс, цитрин, топаз, корал тощо. Також у процеси формотворення композицій вводяться: нейлон, скло, бісер, вулканічна маса, шкіра тощо. 3 початку XXI ст. К. Кравчук - активний учасник найбільш вагомих світових та вітчизняних спеціалізованих виставок, а саме: XXI Міжнародна виставка «HEFAISTON» (Чехія, 2002), X Міжнародна виставка «Ювелір Експо Україна» (Київ, 2005), XXV Міжнародна виставка «HEFAISTON» (Чехія, 2006), III Міжнародний кон-

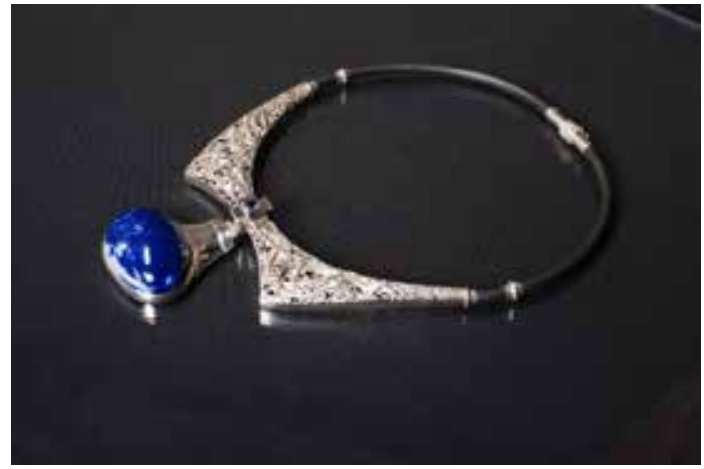

Рис. 4.4. К. Кравчук. Кольє «Благовіст». 2013. Срібло, лазурит, сапфіри. Довільна пластика, авторська техніка, ручне моделювання та монтування. Власність автора. Фото Ю. Дубовика

Fig. 4.4. K. Kravchuk. Necklace «Blagovest». 2013. Silver, lapis lazuli, sapphires. Random plastic, author's technique, manual modeling and mounting. The property of the author. Photo by Yu. Dubovik. 
курс ювелірної моди «Signiti» (Україна, Київ, 2006), виставка «СучаснеювелірнемистецтвоБуковини» (Австрія, Ібзіц, галерея А. Габерман, 2009).

Особливе місце в новітньому українському ювелірстві займає творчість буковинця Штефана Пержана. Глибокою концептуальною філософією звучать твори митця, що тяжіють до абстрактно-геометричних виважених композицій із застосуванням широкої палітри різних матеріалів, що різняться якостями кольору та фактури, несуть змістове навантаження і сприймаються як асоціативні метафори. Художньо-образна архітектоніка ювелірних виробів повною мірою залежить саме від насиченості поліхромії та виразності інтерпретацій кольорових плям різноманітних матеріалів, що використовуються. Конструкції з абстрактних геометричних елементів відтворюють своєрідну естетичну образну мову, де так само, як і у творчості К. Кравчука відчутно вплив авангардного мистецтва та прагнення до пошуків нових оригінальних засобів формотворення. Таким чином, власне специфікою пластичної мови, де використовується потужний арсенал технік ювелірної металопластики, який набутий досвідом майстра ще у 70-х рр. XX ст., абстрактні художні образи трансформуються в оригінальні форми філософського відображення навколишнього світу у творах: перстень «Жага до життя» (2013, срібло, кісточка персика, бурштин, шкіра ската), перстень «Гламур» (ікло мамонта, топази, хризоліт, шкіра ската), кольє (рис. 4.5) «Відродження» (срібло, золото, моховий агат, цирконій, перли), кольє «Край, мій рідний край ...» (срібло, пейзажний агат, мушля, корали, хризоліт), брошка «Святкова» (золото, срібло, мушля, корали), кольє «Святкове» (2012, срібло, корали, цитрин, гранати, опал, перли, перламутр, шкіра, інкрустування перламутром), кольє «Світанок» (2013, срібло, залізне дерево, перли, перламутр, сапфіри,

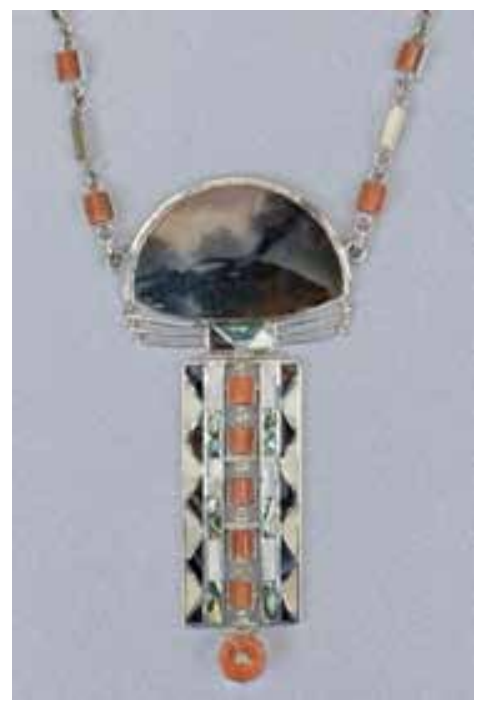

Рис. 4.5. Ш. Пержан. Кольє «Край, мій рідний край». Чернівці. 2011. Срібло, пейзажний агат, перламутр, корали, хризоліти. Випилювання, інкрустація, ручне моделювання та монтування. Власність автора. Фото В. Лопушняка.

Fig. 4.5. S. Perzhan. Collier "The land, my native land». Chernivtsi. 2011. Silver, landscape agate, mother-of-pearl, corals, chrysolites. Sawing, inlaid, manual modeling and mounting. The property of the author.

Photo by V. Lopushniak. 
шкіра, інкрустування сріблом, зернь), браслет «Вікторія» (2013, золото, срібло, гранати, шкіра ската, довільна пластика), кольє «Африка» (2014, срібло, кокос, корали, перламутр, бірюза, бісер, інкрустування сріблом і перламутром, зернь) (Рукотворний світ, 2011, с. 56; Пасічник, 2014, с. 32-34).

Знаковим фактором для поступу львівського ювелірного мистецтва 90-х рр. минулого століття $є$ творчість випускника Естонського державного художнього інституту (м. Таллінн) Віктора Шоломія (1959-2007), який у 1989 р. стояв біля витоків створення кафедри художнього металу у Львівській академії мистецтв (нині ЛНАМ). Митець згуртував навколо себе та дав поштовх для генерування концептуально-філософських ідей формотворення в ювелірстві цілій плеяді молодих художників-ювелірів, які з відвертим захопленням студіювали ювелірне мистецтво за індивідуальною програмою навчання, розробленою В. Шоломієм, що діяла у стінах академіі в 90-х рр. ХX ст. Творчість художника виділяється активним введенням в художньо-образну систему творів елементів алегоричної символіки у поєднанні з креативними методами синтезування різних матеріалів, де основним пріоритетом слугує не вартість матеріалу, а філософська концепція композиції твору. Художник не обмежувався рамками якогось одного стилю та завжди вирізнявся широким діапазоном нових художньо-образних ідей та пошуків методів нового формотворення (Чегусова, 2002, с. 382). Характерною прикметоюутворчості митця сталиалегоричні поетико-фігуративні композиції, що відтворюють формування низки образівархетипів міфологічного чи казкового змісту та додають нової образності у об'ємно-пластичних композиціях (прикрасах). Особливі засоби фігуративної стилізації відкриваються у творах 90-х рр.: кольє «Розбрат» (1996, нейзільберг, раух-топаз, ручне монтування), підвісок «Мрійник» (1997, латунь, корунд, посріблення, ручне монтування), гривна «Світлячки» (1998, нейзільберг, корунди, ручне монтування), брошка «Ангел подарунка» (1999, срібло, ручне монтування), орден «Різдвіна зірка» (1999, срібло, авантюрин, ручне монтування) (Чегусова, 2002, с. 382-383). В. Шоломій виступає провідником нового підходу до формуванні молодих творчих особистостей.

Концепціями різноманітних інтерпретацій, які позначені переосмисленням давньослов'янської міфології, багатством орнаментальних мотивів світової етнокультури, експресивністю та емоційною насиченістю технологічних процесів, пошуком нових виражальних засобів формотворення вирізняється творчість когорти митців-ювелірів, що навчалися за індивідуальною програмою на кафедрі художнього металу ЛНАМ. Серед них - Сергій Микита, Дмитро Ледницький, Орест Івасюта, Роман Велігурський, Ольга Гикова, Віталій Крохмалюк, Едуард Іванюшенко, Олександр Буйвідт, Андрій Кулигін та інші. Ювелірство цих майстрів вирізняється синтезом креативних дизай- 
нерських та технологічних рішень, що в результаті утворюють індивідуальну манеру виконання ювелірного твору (Шафран, 2008, с. 97-100).

Відзначимо, що наближення до національно-культурних основ, форсування художньо-експериментальних ідей та нових методів формотворення, які базуються на традиційних технологіях художнього металу, спрямувало українських ювелірів у русло творчого взаємного обміну. Зауважимо, що обмін інформацією між художниками, майстрами, мистецтвознавцями щодо творчих процесів, які окреслюють різноманітні аспекти вітчизняного та закордонного ювелірства, позитивно вплинуло на поступ новітнього українського ювелірного мистецтва в цілому, відкрило нові сторони стилістики дизайну. Вагомим у становленні та поступі українського ювелірства кін. XX - поч. XXI ст. є відкритість та інформаційна прозорість усіх дизайнерських і технологічних формотворчих процесів, що відбуваються у світі та дають можливість логічно усвідомлювати сутність мистецтва нової епохи. Трансформація давньоруських мотивів у креативні дизайнерські вирішення, використання різних художньо-образних елементів, які ідентифікують ювелірство вітчизняних майстрів саме як українське, виводять його на позиції самодостатніх культур, що активно розвиваються та взаємодіють у просторі світового арт-ринку. Прикладом цього $€$ здобутки українських художників-ювелірів, репрезентовані на різних мистецьких форумах, що систематично відбуваються в багатьох країнах світу. На межі XX-XXI ст. у світі інтенсивно розгортається рух різноманітних міжнародних симпозіумів, фестивалів, конкурсів, виставок та інших спеціалізованих мистецьких акцій, що дали змогу розкритися як молодим, так і вже досвідченим художникам-ювелірам. Активно беручи участь у таких культурно-мистецьких заходах, українські художникиювеліри швидко адаптуються до вже сформованих європейських мистецьких засад та виходять на близькі позиції зі своїми колегами з інших країн, що свідчить про аналітичність мислення та усвідомлення необхідності впровадження креативноінноваційних процесів формотворення, цим самим формуючи сучасну концепцію розвитку українського ювелірства в контексті світового ювелірного мистецтва. Сформувалася чимала когорта митців, які систематично репрезентують свої творчі ідеї та здобутки на різноманітних форумах художнього металу, зокрема в ювелірній справі. Так, починаючи з середини 90-х рр. XX ст. фактично щорічно на всесвітньо відомому симпозіумі «Гефайстон» (Чехія) українські художники-ювеліри традиційно займають призові місця та вражають глибиною образнопластичного і філософського мислення у реалізації ексклюзивних дизайнерських завдань.

З огляду на всі передумови, що виникли після падіння тоталітарної радянської системи, де приватне ювелірство було заборонене та переслідувалося законодавством, не випадково, 
окрім яскравих представників авторського ювелірства, утворюються колективи, які, прогресуючи, у майбутньому стрімко перетворюються на потужні ювелірні компанії. Серед учасників культуро-творчого процесу зазначеної галузі на головні позиції виходять ювелірні фірми, що вирізняються ексклюзивним виконанням ювелірних творів з використанням новаторських креативних конструктивно-формотворчих прийомів, де процеси взаємодії художньо-образної та технологічних складових утворюють композиційні концепції з глибокою філософією. Відзначимо, що активне суперництво в колі визнаних ювелірних брендів повною мірою стимулювало появу на українському та світовому ювелірному арт-ринку нових творів високого мистецького рівня, що вирізняються довершеністю.

Успіхи у творчості українських художників-ювелірів різноманітного спрямування на зламі XX-XXI ст. підтверджують численні нагороди в різних номінаціях на багатьох спеціалізованих міжнародних і всеукраїнських виставках та вказують на початок формування в Україні власної ювелірної школи, що донині через історичні причини не мала передумов для системного розвитку.

Варто зауважити, що українські ювелірні компанії, які досягли певного фахового рівня, сформували власну специфіку виробництва з відчутними акцентами на виразність дизайнерського вирішення, пріоритети використання матеріалів, ефективне раціоналізаторське впровадження до технологічного процесу особливих методів роботи та інших чинників, що створюють імідж ювелірного бренду. Вони, як правило, вирізняються серед загального масиву українського ювелірства, що працює за принципами колективної роботи. За специфікою ідеології принципів та методів роботи на поч. XXI ст. низка ювелірних фірм виокремлюються у традиційні для світового ювелірства форми функціонування, що мають виразні типологічні, технологічні, індивідуальні ознаки, тяжіють до утворення виразних художньо-образних концепцій та, як правило, формуються на певних стилістичних напрямах і локальних стилях. Серед них - відомі нині бренди, а саме: КюД «Лобортас» (м. Київ), Ювелірний дім «Дюльбер» (м. Сімферополь), Ювелірний дім «Кімберлі» (м. Вінниця), Ювелірний дім «Сова» (м. Київ), Ювелірний дім «Заріна» (м. Київ), Ювелірний дім «Оберіг» (м. Київ), Ювелірний дім братів Шуригіних (м. Київ), Ювелірний дім «Karpov\&Karpova Jewellery» (м. Київ) та інші (рис. 4.6; 4.7).

Зазначимо, що серед широкого кола українських ювелірних фірм можна виокремити та кваліфікувати зазначені компанії саме за чітко визначеною стилістикою, специфікою дизайну, формотворчо-технологічних аспектів та ідейно-образною системою. Так в основі принципів роботи КюД «Лобортас» $€$ художньо-експериментальні методи роботи, де поєднання романтичних настроїв у художніх образах та авангардних технологічних ідей на основі традиційних ювелірних технік сфор- 
Деміург: ідеї, технології, перспективи дизайну 2019 Том 2 № 1 Demiurge: ideas, technologies, perspectives of design 2019 Vol. 2 No 1
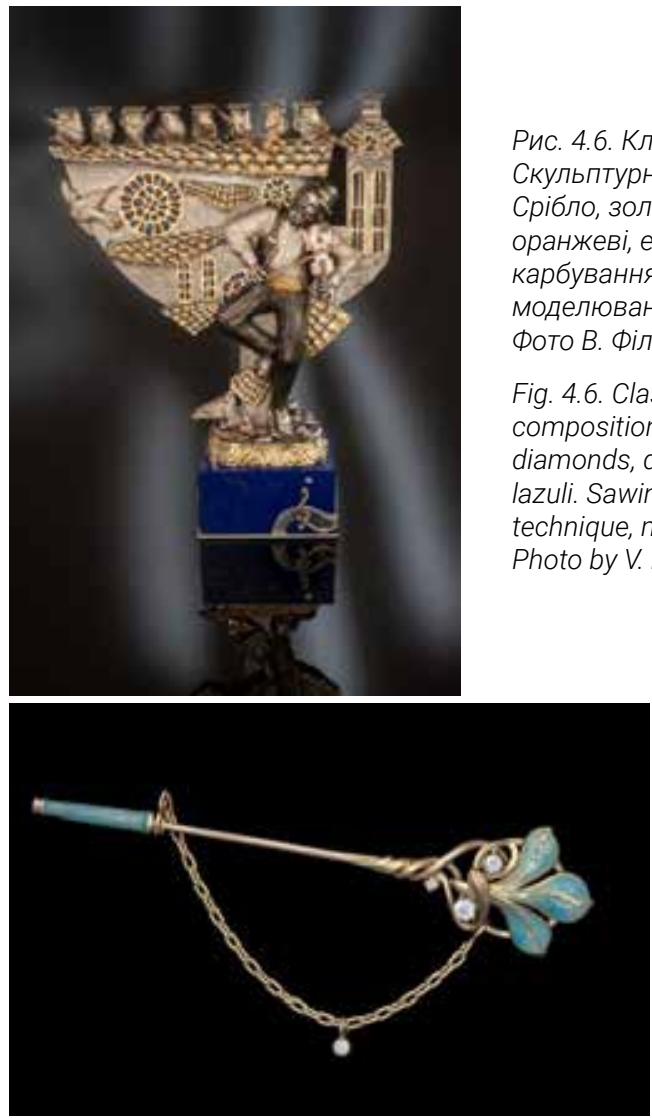

Рис. 4.6. Класичний ювелірний Дім «Лобортас».

Скульптурна композиція «Скрипаль на даху». 2014. Срібло, золото, діаманти, діаманти «коньячні», топази оранжеві, емаль, лазурит. Випилювання, дифування, карбування, гравіювання, техніка гарячої емалі, ручне моделювання та монтування.

Фото В. Філіна.

Fig. 4.6. Classical Jewelry House «Lobortas». Sculptural composition "The Fiddler on the Roof». 2014. Silver, gold, diamonds, diamonds "cognac», orange topaz, enamel, lazuli. Sawing, diffusion, chasing, engraving, hot enamel technique, manual modeling and mounting.

Photo by V. Filin.

мували власний локальний стиль «романтичний авангард», а твори ювелірного дому «Дюльбер» вирізняються традиційними техніками філіграні, скані, зерні, художніх емалей та кримськотатарськими мотивами, що є основними у системі стилізованих символів та знаків композиційних схем ювелірних виробів (Lobortas Classic Jewelry House, 2017-2018; Dyulber Jewelry House, 1999-2019). Слід відзначити, що кожна ювелірна фірма, задекларована як «ювелірний дім», прагне до формування власних виражальних засобів, що визначаються специфікою використання матеріалів, які в синтезі з певними принципами та методами формотворення формують імідж ювелірної компанії.

\section{Наукова новизна та практична значимість дослідження}

Рис. 4.7. Ювелірний дім «Дюльбер». Шпилька «Лілія». 2003. Золото, діаманти, емаль. Випилювання, гравіювання, техніка гарячої емалі по гільйошованій поверхні, ручне моделювання та монтування

Fig. 4.7. Jewelry House «Dyulber». Hairpin «Lilia». 2003. Gold, diamonds, enamel. Sawing, engraving, hot enamel technique on glued surface, manual modeling and mounting. Private collection.

Photo by L. Lytvyn. 
Висновки 6

Узагальнення власних експериментальних аспектів у технологічній площині, активне впровадження у творчий процес прогресивних дизайнерських ідей та напрацьованого за численні роки досвіду попереднього покоління майстрів, що спеціалізувалися у різноманітних кваліфікаціях ювелірного мистецтва, вивело українських ювелірів на новий якісний етап розвитку. Оптимальне співвідношення традиційних методів та новаторських експериментальних чинників технологічного та творчого процесу загалом сформувало загальну концепцію розвитку новітнього українського ювелірства, що характеризується яскравими теоретично-практичними дослідницькими методами та сприяє народженню нових творчих форм реалізації потенціалу українських художників-ювелірів кін. XX - поч. XXI ст. Всі ці аспекти виводять сучасних українських митців ювелірства на шлях ефективної адаптації до нових принципів роботи та трансформації у простір європейського ювелірного арт-ринку, де філософія концепції дизайну, методів синтезу художньообразного та конструктивно-технологічного формотворення $€$ головними чинниками поступу новітнього ювелірного мистецтва України загалом.

\section{Список бібліографічних посилань}

Вольський Станіслав Францевич. (б.р.). Взято з http://www.logos.biz.ua/proj/Inam/online/ Inam--175.pdf.

Кравченко, М. (2014). Мистецькі тенденції авторських прикрас в Україні останньої третини XX - початку XXI століття. Вісник ХДАДМ, 8, 66-69.

Музей історичних коштовностей України. (б.р.). Взято з http://miku.org.ua/yvelirne_mistectvo_ suchasni_ukr_majstri_20st.html.

Пасічник, Л. (2012). Ювелірне мистецтво в контексті художнього процесу останньої чверті XX - початку XXI століття (за матеріалами виставок Києва). Українське мистецтвознавство, 12, 27-36.

Пасічник, Л. (2014). «Квадра міні-метал. Ювелірне - мистецтво - міні-емалі». Київ: Арталекспринт.

Пасічник, Л.В. (2015). Ювелірне мистецтво України XX - початку XXI століття (історія, стилістика, персоналії). (Дисертація кандидата мистецтвознавства). Київ, Інститут мистецтвознавства, фольклористики та етнології імені М. Т. Рильського НАН України.

Рукотворний світ. (2011). (Випуск 4). Київ: Ковальська майстерня.

Чегусова, 3. (2002). Декоративне мистецтво України кінця XX століття. 200 імен. Київ: Атлант Юем Cl.

Шафран, Р. (2008). Особливості професійного ювелірного мистецтва Львова кінця XX століття. Вісник ЛНАМ, 5, 80-102.

Шмагало, Р. (2008). «Замки далекого дитинства». Виставка ювелірних виробів та художніх емалей Станіслава Вольського. 1-11 грудня 2008 р. Взято з www.mundm.kiev.ua/ EXHIBIT/VOLSKIY.SHTML.

Шмагало, Р. (2012). Ювелірне мистецтво України: авторський пошук і ринок. Образотворче мистецтво, 3-4, 34-35.

Шмагало, Р. (2015). Художній метал України XX - початок XXI століття. Енциклопедія художнього металу. (Т. 2). Львів: Апріорі.

Bennett, D., \& Mascetti, D. (2003). Understanding jewellery. Antique Collectors'Club Ltd.

Dyulber Jeweller House. (1999-2019). Retrieved from dyulber.com/mainpage.php.

Lobortas Classic Jewelry House. (2017-2018). Retrieved from http://lobortas.com/en/. 


\section{References}

Volskyi Stanislav Frantsevych. (n.d.). Retrieved from http://www.logos.biz.ua/proj/Inam/online/ Inam--175.pdf [in Ukrainian].

Kravchenko, M. (2014). Mystetski tendentsii avtorskykh prykras $\vee$ Ukraini ostannoi tretyny $X X$ - pochatku XXI stolittia [Art tendencies of author's decorations in Ukraine of the last third of XX - beginning of XXI century]. Visnyk KhDADM, 8, 66-69 [in Ukrainian].

Muzei istorychnykh koshtovnostei Ukrainy [Museum of Historical Treasures of Ukraine]. (n.d.). Retrieved from http://miku.org.ua/yvelirne_ mistectvo_suchasni_ukr_majstri_20st.html [in Ukrainian].

Pasichnyk, L. (2014). "Kvadra mini-metal. Yuvelirne - mystetstvo - mini-emali" ["Quadra mini-metal. Jewelery - art - mini-enamels"]. Kyiv: Artaleks-prynt [in Ukrainian].

Pasichnyk, L. (2012). Yuvelirne mystetstvo v konteksti khudozhnoho protsesu ostannoi chverti XX - pochatku XXI stolittia (za materialamy vystavok Kyieva) [Jewelery art in the context of the artistic process of the last quarter of the $X X$ - beginning of the $X X I$ century (based on the materials of Kyiv exhibitions)]. Ukrainske mystetstvoznavstvo, 12, 27-36 [in Ukrainian].

Pasichnyk, L.V. (2015). Yuvelirne mystetstvo Ukrainy XX - pochatku XXI stolittia (istoriia, stylistyka, personalii) [Jewelery art of Ukraine XX - beginning of the XXI century (history, stylistics, personalities)]. (Candidate's thesis). Kyiv, Rylsky Institute of Art Studies, Folklore and Ethnology [in Ukrainian].

Rukotvornyi svit [Man-made world]. (2011). (Issue 4). Kyiv: Kovalska maisternia [in Ukrainian].

Chehusova, Z. (2002). Dekoratyvne mystetstvo Ukrainy kintsia XX stolittia. 200 imen [Decorative art of Ukraine at the end of the twentieth century. 200 names]. Kyiv: Atlant Yuem SI [in Ukrainian].

Shafran, R. (2008). Osoblyvosti profesiinoho yuvelirnoho mystetstva Lvova kintsia XX stolittia [Features of professional jewelry art of Lviv at the end of the twentieth century]. Visnyk LNAM, 5, 80-102 [in Ukrainian].

Shmahalo, R. (2008). "Zamky dalekoho dytynstva". Vystavka yuvelirnykh vyrobiv ta khudozhnikh emalei Stanislava Volskoho. 1-11 hrudnia 2008 r. ["Locks of a distant childhood". Exhibition of jewelry and art enamels by Stanislav Volsky. December 1-11, 2008]. Retrieved from www.mundm.kiev.ua/ EXHIBIT/VOLSKIY.SHTML [in Ukrainian].

Shmahalo, R. (2015). Khudozhnii metal Ukrainy XX - pochatok XXI stolittia. Entsyklopediia khudozhnoho metalu [Art Metal of Ukraine XX - the beginning of the XXI century. Encyclopedia of artistic metal]. (Vol. 2). Lviv: Apriori [in Ukrainian].

Shmahalo, R. (2012). Yuvelirne mystetstvo Ukrainy: avtorskyi poshuk i rynok [Jewelery Art of Ukraine: author search and market]. Obrazotvorche mystetstvo, 3-4, 34-35 [in Ukrainian].

Bennett, D., \& Mascetti, D. (2003). Understanding jewellery. Antique Collectors'Club Ltd [in English]. Dyulber Jeweller House. (1999-2019). Retrieved from dyulber.com/mainpage.php [in English]. Lobortas Classic Jewelry House. (2017-2018). Retrieved from http://lobortas.com/en/ [in English]. 